\author{
Imanaliyeva S.S. ${ }^{1}$ \\ ${ }^{I}$ Ablai khan KazIR and WL, \\ Almaty, Kazakhstan
}

\title{
THE ROLE OF PERSONALLY ACTIVE APPROACH IN FUTURE TEACHERS' FOREIGN LANGUAGE PROFESSIONAL COMPETENCE FORMATION
}

Abstract

This article aims to identify the definition and the role of personally active approachin future teacher's foreign language professional competence. Initially, it observes the relevance of the issue of foreign language education and new paradigm in education system globally and in Kazakhstan. Also, the author analyzes different scholars' opinions about a professionally competent foreign language teacher and his characteristics, supporting it with state and international educational documents. The article also observes the definitions of personally active approach and its usage in education. Furthermore, the article deals with arguments proving the role of personally active approach in future teachers' foreign language professional competence formation. Analyzing the data from various scientific papers, articles and books, state and international educational standards, the author makes a conclusion in the end of the article.

Key words: personally active approach, professionally competent teacher,competence, components, characteristics, importance, future teacher.

\author{
Иманалиева С.C. ${ }^{1}$ \\ ${ }^{1}$ Абылай хан ат. ҚазХҚ және ӘТУ, \\ Алматы қ., Қазақсттан
}

\section{БОЛАШАҚ МҰҒАЛІМДЕРДІН БОЙЫНДА ШЕТТІЛДІК КӘСІБИ БІЛІКТІЛІКТІ ҚАЛЫПТАСТЫРУДАҒЫ ТҰЛҒАЛЫҚ-ІС-ӘРЕКЕТТІК ТӘСІЛІНІН РОЛІ}

\section{Aң̧датпа}

Берілен мақала болашақ мұғалімдердің бойында шеттілдік кәсіби біліктілікті қалыптастырудағы тұлғалық-іс-әрекеттілік тәсілінің анықтамасын және ролін айқындауды көздейді. Бастапқыда мақала Қазақстан мен жаһандану жағдайындағы жалпы білім жүйесінің және шеттілдік білім берудің жаңа парадигмасына көшу өзектілігін қарастырады. Автор кәсіби құзыретті шетел тілі пәнінің мұғалімі және оның қасиеттері жайлы жазылған түрлі ғалымдардың ойын жинақтап, талдайды. Оған қоса мақалада тұлғалық-іс-әрекеттік тәсілдің анықтамасы мен оның білім беру процесіндегі қолданысы жайлы айтылады. Оған қоса мақалада тұлғалық-іс-әрекеттік тәсілдің болашақ мұғалімдердің бойында шеттілдік кәсіби біліктілігінің қалыптасуындағы ролін айқындайтын аргументтер беріледі. Түрлі ғылыми жұмыстарды, мақалаларды, оқулықтарды, мемлекеттік және халықаралық білім стандарттарын талдай отырып, автор қорытынды жасайды.

Түйін сөздер: тұлғалық-іс-әрекеттілік тәсіл, кәсіби білікті шетел тілі пәнінің мұғалімі, біліктілік, компоненттер, қасиеттер, маңыздылық, болашақ мұғалім.

\author{
Иманалиева C.C. ${ }^{1}$ \\ ${ }^{1}$ КазУМОимЯ им. Абылай хана, \\ 2. Алматы, Казахстан
}

\section{РОЛЬ ЛИЧНОСТНО-ДЕЯТЕЛЬНОСТНОГО ПОДХОДА В ФОРМИРОВАНИИ ИНОЯЗЫЧНОЙ ПРОФЕССИОНАЛЬНОЙ КОМПЕТЕНЦИИ У БУДУЩИХ УЧИТЕЛЕЙ}

\author{
Анноттация
}


Данная статья нацелена на выявления определения и роли личночтно-деятельностного подхода в формировании иноязычной профессиональной компетенции у будущих учителей. В статье рассмотрена актуальность перехода на новую парадигму системы образования и иноязычного образования в Казахстане в условиях глобализации. Автор приводит определения ученых терминов «профессионально-компетентный учитель иностранного языка» и «личностно-деятельностный подход». В статье также анализируются разные точки зрения учёных о профессиональной компетентности учителя иностранного языка и его характеристиках, о роли личностнодеятельностного подхода в формировании иноязычной профессиональной компетенции у будущих учителей. Проанализировав разные научные работы, статьи, государственные и международные образовательные стандарты, автор приводит заключение, где обобщает данные о роли личностнодеятельностного подхода в формировании иноязычной профессиональной компетенции у будущих учителей.

Ключевые слова: личностно-деятельностный подход, профессионально-компетентный учитель, компетентность, компоненты, характеристика, важность, будущий учитель.

Introduction. Socio-economic, political and socio-cultural reforms in our country, already done or upcoming are reasoned by global changes in the world in general, and they lead to big changes in educational system. Among significant ones we can nametransitiontoamulti-levelsystemoftrainingspecialists, integrationintotheglobaleducationalsystem. Highdemands to undergraduates in our country are conditioned by strong competitiveness on labor market, also widening of scientific and business contacts with foreign countries, which demands the correspondence the specialist's knowledge to international standards. The current level of socio-economic development in Kazakhstan is featured by changing all society structures, and it is naturally that educational paradigm also changes and becomes more personal-oriented than common, which in its turn provides the possibility of a person's effective professional function in postindustrial society conditions.

Today it is obvious that educational system needs not just some amendments, but more structural and fundamental changes according to the needs of the modern society. Among lots of objectives of pedagogical science in high educational system the special attention is paid to integrating personal-oriented approach, considering informative, emotional and willing characteristics of a student.

The humanization of education is also a need. According to Kozyrev V.A. the humanization of education system means that acquired knowledge is to become personally significant for each student. In this case it becomes real instrument for society development. At the same time the process of acquiring knowledge should be deliberately directed on revealing the inner potential of a person, his personal development. In other words, it should be personal-oriented. [1;2].

However, although the traces of personal-oriented approach were seen in philosophy of individual scientists, the whole picture of educational system didn't seem to change, that is why the necessity of promoting a person to the first and main role of a teaching process needed to change the traditional way of teaching into personally-oriented professional education, which is based on the possibility of self-education, self-defining, independence and self-realization in every-day and professional spheres.

\section{Defining the term and therole of personally active approach in future teachers' foreign language professional competence formation}

While analyzing fundamental works on pedagogy and methodology of education we have faced an interesting tendency, that great scientists' thoughts can be similar in different decades and even centuries. Thus, according to Elkonin the learning activity is oriented on the subject's development and selfdevelopment. That is why personally active approach can be defined from two sides: both teacher's and learner's position [3]. As we see today's new education paradigm also focuses on two-sided analysis of the educational process, where a learner is not a passive object of education, but also an active participant of it. Moreover, a learner has become the main subject of a learning process, which proves Elkonin's idea.

Nearly the same idea we can observe in psychology, where personally active approach basics are researched by the following scientists: Vygotsky [4], Leontyev [5], Rubenshtein [6]. In their works a person is defined as a subject who is formed during the communication and interaction with others. This also one of the main criteria of today's education paradigm, where a learner is a subject and there must be not only traditional frontal work as teacher-student, but also pair work, group work and team work, while doing which learners may exchange knowledge withing each other. 
At the end of the 80 s "Teacher's creativity is a learner's creativity" was one of the main moto in pedagogy. The teachers' opinion at that time corresponded in the idea that the teacher is a person who truly loves his/her job, may pay attention to everyone in the classroom and may organize the teaching process, so that everyone can be involved in the lesson, and whose love and respect towards learners is clearly seen. If to analyze the philosophy of that time's pedagogy we can clearly see the trace of personally active approach which was used by famous pedagogy representatives as A.S. Makarenko [7] and V.A. Shomlinsky in their methodology [8].

Suhomlinsky once wrote "All the three thousand seven hundred pages of my teaching biography is dedicated to only one person - my student" [8]

A.S. Makarenko's methods should be used in all educational institutions in my opinion, because labour, a good and equal rapport between a teacher and a learner, pedagogical mastery, lifelong learning, experiment and other principles are the characteristics of a competent teacher today[7].

Shatalov's individual approach is dedicated to everyone; although everyone works with individual work, but not everyone is evaluated for that. The learner who wants to get a higher mark may correct and get higher points. It decreases learner's anxiety [9].

All these scholars' thoughts are followed in one direction, to the direction of a learner. The learner's interests, motives and needs should come first.

Defining personal-active approach as a complex of its personal and active components we may surely say that the first one is related to personal or as it is defined lately personal-oriented approach (I.S. Iakimanskaia, Y.V. Bondarevskaia, M.N. Berulava, V.V. Serikov and others). Personal approach supposes that all psychological processes, features and conditions are considered to be owned to one person, that they depend on individual and social existence of a human and defined his/her laws. [10].

Personal approach according to K.K. Platonov is a principle of personal conditioning of all psychological beings of a human, his/her activity, his/her individual-psychological features [11].

Personally-active approach supposes that in the center of teaching process is a learner himself, his motives, aims, his individual psychological structure, that is a learner as a person. Teacher in his turn, defines the educational aim, and organizes the whole educational aim taking into account learner's interests, level of knowledge and skills. Thus, while using personally-active approach, the aim of every lesson is formed from the position of each students a person, and the whole group in general.

For instance, such task as "analyze your last six months and write a report of your achievements, problems and reasons for them, possible solutions of your problems in learning English" may surely be considered as personally-oriented one, as it gives an opportunity to self-evaluation, by giving the feedback of your own work and gives the teacher to put individual aims according to the results of their work.

The development of personal-oriented professional education, which supposes the usage of the personally active approach there should be considered some causes of changing the educational paradigm:

- the membership in the Bolognian process and its implementation in Kazakhstani context;

- the integration of the country in the world economic commune demands a high level of professional education in Kazakhstan to meet the global standards of labor market;

- the change of the foreign education content according to which a learner and his/her personal development became the main target of the education;

- the more humanistic direction of the education;

- the orientation on individual learning styles, motives and learners' psychological conditions.

Integrational processes in science, industry and education demands the deep analysis and the fundamental change the whole structure and philosophy of professional education of a future specialist. The idea of humanistic education is to make it possible to develop as a person, to form highly educated and multi-functioned citizens, who are ready not only acquire knowledge, but also to generate new ideas [12]

The personally active approach supposes to imply subject-subject relationships between the teacher and the student to make the learner feel not the object of educational process, but the active participant of it.

A big attention while using personal-oriented approach is paid to individual work of a student. The teacher stops being a dominant authority in the classroom and becomes a guide, a facilitator and an organizer of the educational process. However, it doesn't mean that the teacher's role has decreased, visa versa, the teacher's personality and professionalism play the main role for successful learning. Nowadays, the demand to the teacher is much higher than before. The teacher has to be not only educated and motivated to work, but also has to solve different cases, should be demanding and understanding at the same time, should be smart 
and tactful. Also, the teacher should never stop learning and dedicate time to self-development whether in professional sphere or as just a person in order to be aware of innovations.

Nevertheless, to exclude the activity and using only personal-oriented approach would be a big mistake, because as Rubenstein mentioned in his works "to make the personal aspect the only one to use is to restrict the way to research psychologic activity laws". During the learning process the personal development is closely connected within the activity. A lot of scholars worked on theory of activity, in general pedagogics, for instance, I. Pestalocci, A.Disterveg and others. S.L.Rubenstein and F.N.Leontyev made their researches from the point of view of general psychology. And the theory of learning activity was researched by D.B. Elkonin, V.V. Davydov and A.K. Markova.

As the terms "action" and "activity" are different according to Leontyev, their aims are also different. He explains this difference by his example of reading books. When a learner read a book because he wants to learn something new, which is interesting for him/her. The learner is disappointed when he/she is interrupted and reluctantly stops reading. This is supposed to be an activity, because the aim and the motive are reasoned with the desire to learn, in other words cognition. And, "action" in its turn has a different aim, for example, when you read a book not because you are interested and want to know something new, but because of the exam. The learner has different motives to read it, they can be as strong as activity motives, but they are short-time aims and motives, because the learner does it reluctantly and has no desire to continue.

Although, both of them have motives and a "need" to be done, because without a need there will be no action. However, the need itself does not define an activity, it is defined by what it is oriented on, it receives its orientation in the subject of the activity. For example, the teacher's activity is oriented on sharing sociocultural experience with learners, learner's activity is oriented on acquiring the knowledge. The main characteristic of an activity is having a motivation. Motivation can be of two types inner, which is more likely to be communicative and long-term, and outer motivation which also can be as strong as inner one, however, it does not last long.

So, as these notions differ in their aims and motives, activity is more likely to be oriented on communication, which in its turn is the basis of the learning process. It is significant to say that according to Leontyev a person consciously puts a definite sense in doing any kind of action and corresponds it with a motive of an activity. At the same time an action can and in the learning process should become a conscious operation [5]. Thus, according to Bernshtein, when the teacher trains a sound in foreign language teaching becomes "a conscious" operation when the learner realizes that the sound is necessary to learn a word or a phrase. It is always easy to work with learners when they realize the motive and aim of any mechanic action, which later becomes an activity [13]

To sum up, a personally active approach is a tool to help learners to be actively involved in the learning process. The teacher who uses a personally active approach organizes a learning process according to learner's needs, motives and possibilities, which in its turn gives an opportunity to personal and professional development of a learner individually, not following the average standards of education. If a teacher organizes the learning process correctly, taking into account all the principles of an personally active approach, it gives an opportunity to facilitate the learning process for students with individual learning styles.

Conclusion. The distinctive feature of today's educational process condition is defined as dynamic transition of sociogenesis. We cannot adhere the traditional educational system and approaches while the world around us is changing dynamically. Today the future specialist doesn't know precisely how much he/she is in demand in the labor market, in society in general. Thus, the problem of socialization arises, some cannot adjust the quick changes within the society like reformations, political or economical situations as well as others can. Moreover, young people today are more responsible for their own future, because these changes make them to choose the professional path consciously. That is why the higher educational institutions have to create conditions to develop a person who is widely educated, who can think critically and is flexible to society changes.

In general, personally-active approach in learning process means that it is oriented on the main objective of the education - the creation of conditions for the development of the person who is able to solve every day problems as well as professional issues, who thinks critically and morally ready to social changes and flexible to any crisis. The personal component of this approach means that the whole learning process is aimed and organized taking into consideration a person's previous experience, his/her personal and psychological characteristics, his/her motives, values, aims and interests. 
1. Новиков А.М. Профессиональное образование России. Перспективы развития. М.: ИЦПНПО РАО, 1997.Стр 254- книга

2. Новичкая Т.М. Организачия обучения иностранным языкам с применением ТСО: Обзорная информация НИИ ВШ. М., 1962.Стр 44 - научная статья

3. Эльконин Б.Д. Избранные психологические труды. М.: Педагогика, 1989 - книга

4. Выготский Л.С. Игра и ее роль в психическом развитии ребенка //Психология развития. - СПб: Питер, 2001. - книга.

5. Леонтьев А.Н. Деятельность. Сознание. Личность. / А.Н. Леонтьев. 2-е изд. -М.: Политиздат, 1977.- 304c.

6. Рубинштейн С.ЈT. Основы общей психологии. СПб.: Питер. Ком, 2003 - книга

7. Макаренко А.С. Педогогические сочинения М; Педагогика 1986 - книга

8. Сухомлинский В.А. О воспитании М; Политическая литература 1982- книга

9. Шатилов С.Ф. Основные направления педагогизащии и профессионализации учебного процесса на факультете иностранных языков педагогического вуза: Сб. статей,- Л.: ЛГПИ им. А.И.Гериена, 1975,- C. 7281.

11. Платонов, К. К. «Структура и развитие личности». Наука М. - 1986- книга

12. ЗеерЭ. Ф. Личностно ориентированное профессиональное образование /; Урал. гос. науч.образоват. иентр Рос. акад. образов., Урал. гос. проф.-пед. ун-т. - Екатеринбург : Издательство УГППУ, 1998. - 125 с. : ил., табл.с. 122-123.

13. Бернштейн М.С. Индивидуальный характер усвоения и индивидуализачия обучения // Вопросы психологии. 1975. №2. - С. 136-146. - научная статья

МРНТИ 14.35.09

https://doi.org/10.51889/2020-2.1728-5496.41

Tilimissova D.S. ${ }^{1}$ Yessengaliyeva A.M. ${ }^{2}$

${ }^{1,2}$ L.N. Gumilyov Eurasian National University, Nur-Sultan, Kazakhstan

\title{
USING ICT IN CLIL CLASSROOM AT THE TERTIARY LEVEL: ECONOMICS STUDENTS' RESULTS
}

Abstract

The article discusses issues related to the use of information and communication technologies in the learning process in the context of Content and Language Integrated Learning. The process of implementing information technology in education is quite complex and requires deep reflection. The article discusses the possibilities of using Internet resources as a means of learning within the CLIL. The authors conducted a study on the basis of the L. N. GumilyovEurasian National University, majors: "5B050900-Finance"," 5B050800-Accounting and audit". The methodological basis of experimental work on the development of professional foreign language competence by students of economic specialties was the concept of practiceoriented professional training as well as to develop technology competency integrated into EFL environment.

Keywords: CLIL, ICT, QR-code, EFL, mobile learning

$$
\begin{gathered}
\text { Тилимисова Д. С. }{ }^{1}, \text { Есенгалиева А. } \text { M. }^{2} \\
{ }^{12} \text { Л.Н.Гумилев атындавы Еуразия ұлттық университеті } \\
\text { Нұр-Сұлтан қ., Қазақсстан, }
\end{gathered}
$$

\section{CLIL КОНТЕКСТІНДЕГІ САБАҚТА АҚПАРАТТЫҚ-КОММУНИКАЦИЯЛЫҚ ТЕХНОЛОГИЯЛАРДЫ ЖОҒАРЫ БІЛІМ ДЕНГЕЙІНДЕ ҚОЛДАНУ: ЭКОНОМИСТ-СТУДЕНТТЕРДІН НӘТИЖЕЛЕРІ}

\author{
Aң̧датnа
}

